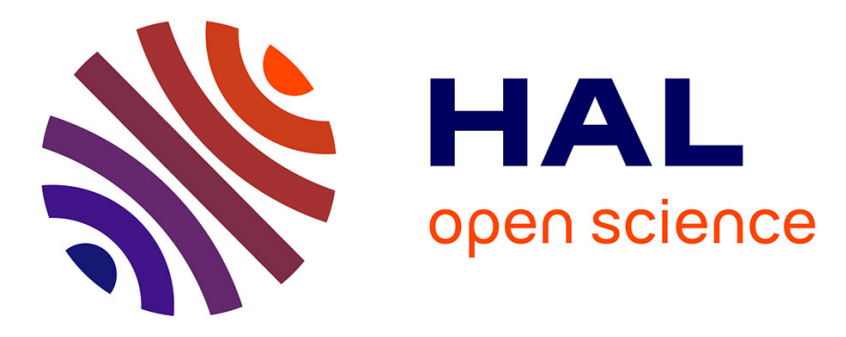

\title{
The Lexicon-Grammar of Predicate Nouns with ser de in Port4NooJ
}

\author{
Cristina Mota, Jorge Baptista, Anabela Barreiro
}

\section{To cite this version:}

Cristina Mota, Jorge Baptista, Anabela Barreiro. The Lexicon-Grammar of Predicate Nouns with ser de in Port4NooJ. Mirto, Ignazio Mauro; Monteleone, Mario; Silberztein, Max. Formalizing Natural Languages with NooJ 2018 and Its Natural Language Processing Applications, Springer, pp.124-137, 2019, 978-3-030-10868-7. 10.1007/978-3-030-10868-7_12 . hal-03017777

\section{HAL Id: hal-03017777 https://hal.science/hal-03017777}

Submitted on 21 Nov 2020

HAL is a multi-disciplinary open access archive for the deposit and dissemination of scientific research documents, whether they are published or not. The documents may come from teaching and research institutions in France or abroad, or from public or private research centers.
L'archive ouverte pluridisciplinaire HAL, est destinée au dépôt et à la diffusion de documents scientifiques de niveau recherche, publiés ou non, émanant des établissements d'enseignement et de recherche français ou étrangers, des laboratoires publics ou privés. 
See discussions, stats, and author profiles for this publication at: https://www.researchgate.net/publication/329904196

\section{The Lexicon-Grammar of Predicate Nouns with ser de in Port4NooJ: 12th International Conference, NooJ 2018, Palermo, Italy, June 20-22, 2018, Revised Selected Papers}

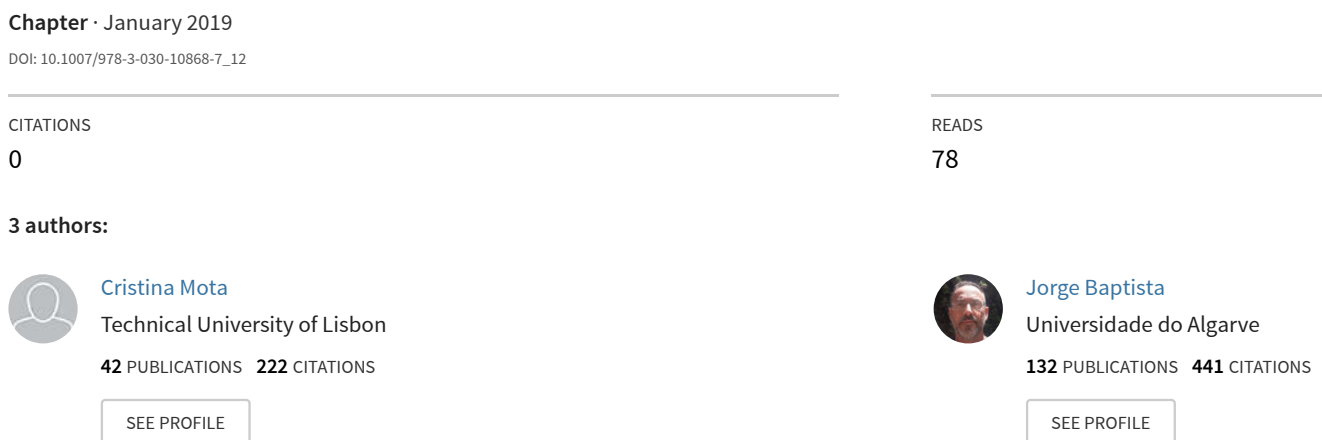

Some of the authors of this publication are also working on these related projects:

Project Language Resources for Portuguese NLP View project

Project eSPERTo - System for Paraphrasing in Editing and Revision of Text View project 


\title{
The Lexicon-Grammar of Predicate Nouns with ser de in Port4NooJ
}

\author{
Cristina Mota ${ }^{1}$ Jorge Baptista $^{2}$, and Anabela Barreiro ${ }^{3}$ \\ 1 L2F/INESC-ID \\ cmotaeist.utl.pt \\ 2 Universidade do Algarve \& L2F/INESC-ID \\ jbaptis@ualg.pt \\ 3 L2F/INESC-ID \\ anabela.barreiroeinesc-id.pt
}

\begin{abstract}
This paper provides continuity for previous efforts on the integration of complementary lexicon-grammars to expand the paraphrastic capabilities of Port4NooJ, the Portuguese module of NooJ (Silberztein 2016). We describe the integration of the lexicon-grammar of 2,085 predicate nouns, which co-occur in constructions with the support verb ser de 'be of' in European Portuguese, such as in $O$ Pedro é de uma coragem extraordinária 'Peter is of an extraordinary courage', studied, classified and formalized by Baptista (2005b). This led to a $20 \%$ increase in the number of predicate nouns. We also extended previously created paraphrasing grammars, such as the grammars that paraphrase symmetric predicates, as well as the grammars that handle the substitution of the support verb by another support verb. Furthermore, we created new grammars to paraphrase negative constructions, appropriate noun constructions, adjectival constructions, and manner sub-clauses. The paraphrastic capabilities acquired have been integrated in the eSPERTo system.
\end{abstract}

\section{Introduction}

Previous research has shown that the distributional and transformational properties of adjectival and nominal predicates contained in lexicon-grammar tables can be used in paraphrasing tasks with successful results. Mota, Carvalho, and Barreiro (2016) describe the integration of the lexicon-grammar of human intransitive adjectives formalized by Carvalho (2007), and Mota, Chacoto, and Barreiro (2017) describe the integration of the lexicon-grammar of the predicate nouns co-occurring with the support verb fazer 'do' or 'make' formalized by Chacoto (2005).

This paper provides continuity for previous efforts on the integration of complementary lexicon-grammars to expand the paraphrastic capabilities of Port4NooJ, the Portuguese module of NooJ (Silberztein 2016). We describe the integration of the lexicongrammar of 2,085 predicate nouns, which co-occur in constructions with the support verb ser de 'be of' in European Portuguese, such as in $O$ Pedro é de uma coragem extraordinária 'Peter is of an extraordinary courage', studied, classified and formalized by Baptista (2005b). Many of these predicate nouns correspond to the nominalization of adjectival constructions, so in those cases they are linked to the corresponding adjective 
in the lexicon-grammar table. This presents a major challenge in terms of integration into Port $4 \mathrm{NooJ}$, as in $55 \%$ of the cases where the predicate nouns have an equivalent adjectival construction, the adjective is homograph of a human intransitive adjective, already formalized in the lexicon-grammar of human intransitive adjectives. This means that one must find a way of harmonizing these entries so as not to have duplicates. However, for now, we did not tackle this challenge and will not discuss it further.

The predicate nouns that occur with the support verb ser de were classified into nine classes. The criteria to establish those classes are described in Section 3. The structural, distributional, and transformational properties represented in the lexicon-grammar table for each predicate noun led to the generation of a variety of paraphrases, which are achieved by different lexico-syntactic processes. One of these processes is the interchangeability with other elementary support verbs, such as ter 'have' or haver 'there be', and more rarely with fazer 'do' or 'make'. Some paraphrastic relations have also been established based on the (i) insertion of negation/negative prefixes (mainly desand in-) on predicate nouns, (ii) complementary but analytical mechanism of negation involving the expression falta de 'lack of', (iii) NP restructuring, (iv) predicate nouns that can function as an adnominal adjunct of a common human noun, (v) predicate nouns most likely obtained from the reduction of complex sentence with a relative clause, and (vi) symmetric predicate noun constructions.

As in previous integration efforts, the resources gathered are to be incorporated into the eSPERTo paraphrasing system ${ }^{4}$ and to be used in a wide variety of software applications, so as to allow rephrasing a sentence or text using different words. The evolution of eSPERTo's resources, starting from the original Port4NooJ to the current version, which integrates several lexicon-grammars, among other resources, is illustrated in Figure 1. The combination of the different resources enables a large number of paraphrases that are increasing in volume and improving in quality. We plan to enlarge our growing database of pairs of paraphrastic units by converting more tables built (or to be built) for Portuguese or other languages at the same time as we evolve our integration of crowdsourcing and machine learning techniques to acquire raw data that require validation by linguists before integrating into the paraphrasing engine. Our methodology is based on grammar and other processes that we believe are the ones used by the human brain in processing language (Barreiro et al. 2011; Scott 2018).

\section{Related Work}

In our several scientific papers on the work towards increased integration of lexicongrammar tables, we have referred to related published works on support verb constructions studied within the lexicon-grammar theory (Gross 1975; Gross 1996), for several Romance languages other than Portuguese (D'Agostino and Elia 1998; Laporte and Voyatzi 2008; Silberztein 1993), and contrastive studies aiming at machine translation between English and French (Salkoff 1990). Many of the studies within the lexicongrammar framework focus on formalization of multiword units, most of them on the topic of support verb constructions. As for the Portuguese language, several detailed

\footnotetext{
${ }^{4}$ eSPERTo, which means 'smart' in Portuguese, stands for "System of Paraphrasing for Editing and Revision of Texts" ("Sistema de Parafraseamento para Edição e Revisão de Texto").
} 


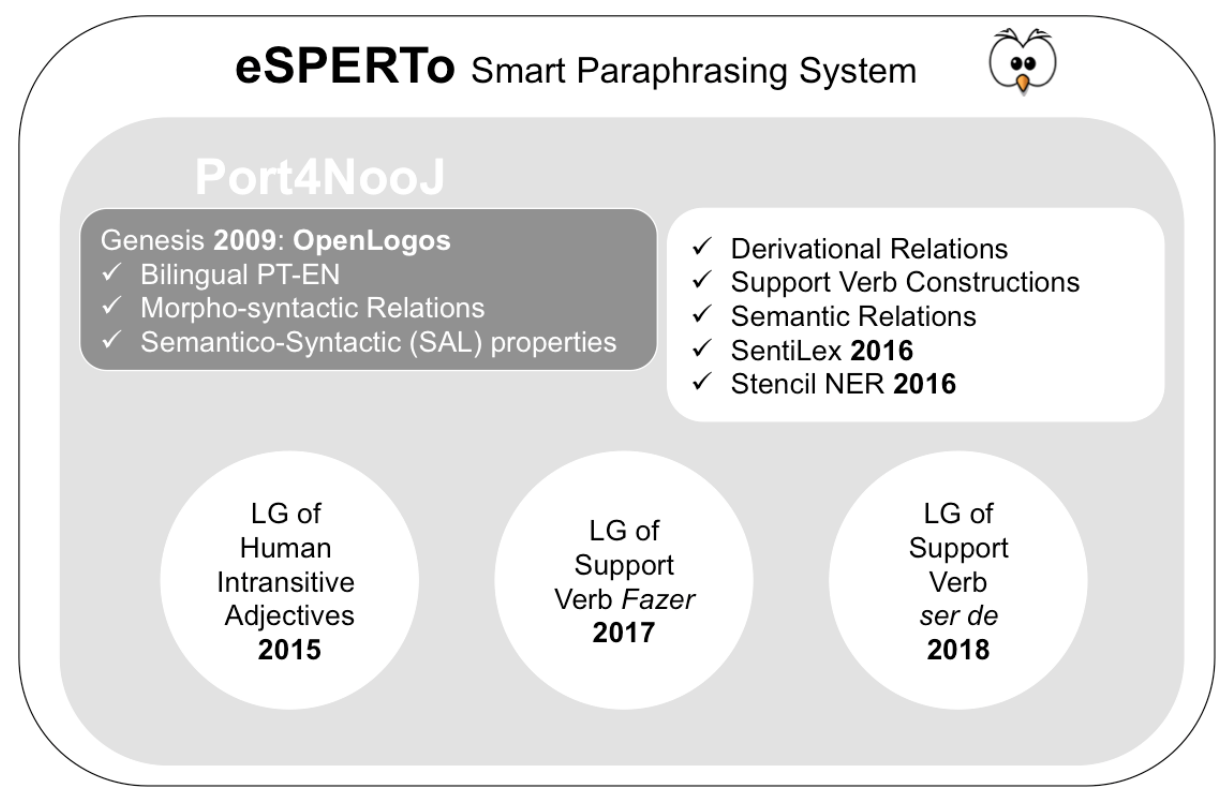

Fig. 1: Evolution of eSPERTo Paraphrasing System

studies on support verb constructions have become an established theme in development cooperation, which have been presented at the last four International NooJ Conferences, addressing the integration of relations between support verbs and nominalizations (normally autonomous predicate nouns) or predicate adjective constructions Each one of those papers also illustrates how the properties contained in the addressed lexicon-grammar tables are used in paraphrasing tasks.

The very first integration experiment by Mota, Carvalho, and Barreiro (2016) concerned the integration of the lexicon-grammar of human intransitive adjectives into the Port 4 NooJ module. After the success of this integration, we have started to integrate complementary lexicon-grammars, first the lexicon-grammar of predicate nouns, which co-occur with the support verb fazer (Mota, Chacoto, and Barreiro 2017), and now the lexicon-grammar of predicate nouns co-occurring with ser de. Several classes and subclasses have been defined for each one of these lexicon-grammars based on distributional and transformational properties of the predicate nouns with which each one of these verbs co-occurs. The main properties of the transformations of ser de that we represented in paraphrasing grammars are described in Section 3. As far as we know, no other similar integration efforts have been done for any other language, at least within the NooJ framework ${ }^{5}$.

\footnotetext{
${ }^{5}$ In Rassi et al. 2014; Rassi et al. 2015, a proposal is presented for the integration of predicate noun constructions into STRING (Mamede et al. 2012), a hybrid, rule-based and statistical, natural language processing chain, specifically developed for the processing of Portuguese.
} 


\section{Lexicon-Grammar of Predicate Nouns with $V_{\text {sup }}$ ser de}

The lexicon-grammar of predicate nouns occurring in constructions with the support verb ser de 'be of' in European Portuguese, such as in $O$ Pedro foi de uma ajuda inestimável para a Ana 'Pedro was of an invaluable help to Ana' was formalized by Baptista (2000, 2005b) after studying and classifying the structural, distributional, and transformational properties of 2,085 predicate nouns. The author identified seven classes of predicate nouns according to (i) the number or arguments (1 or 2) selected by the predicate noun, (ii) the syntactic (sentential/nominal) constraints, and (iii) the distributional (semantic) selection constraints on the nominal argument slots (human/non-human). Two special classes were established for: (i) nouns selecting a body-part noun as their subject, such as Os músculos da Ana são de uma tonicidade impressionante 'Ana's muscles are of an impressive tonicity', and (ii) constructions that have an equivalent symmetric construction, i.e., allow swapping the predicate noun's subject with its complement, such as A Ana é de uma grande parecença com a irmã 'A Ana is of a great resemblance to her sister'. Table 1 presents the breakdown of these nouns by classes and their basic syntactic structure. Of the many transformations formalized in this lexicongrammar we chose a few to start creating paraphrasing grammars. In 3.1-3.7, we will briefly describe some of its properties.

\subsection{Symmetry Restructuring}

In symmetric predicates (see Baptista 2005a for an overview in Portuguese), their two arguments have the same semantic role in relation to the predicate and, therefore, they can be swapped in their syntactic slots without changing the overall meaning of the sentence, e.g., A aldeia é de uma proximidade à praia muito grande = A praia é de uma proximidade muito grande à vila 'The village is of a great proximity to the beach' = 'The beach is of a great proximity to the beach'; or be coordinated in the same syntactic slot (the subject), e.g., A vila é de uma grande proximidade à praia $=A$ vila e a praia são de uma grande proximidade (uma da outra) 'The village is of a great proximity to the beach' = 'The village and the beach are of a great proximity (to each other)'.

\subsection{Support Verb Variants}

Usually, the support verb occurring with a predicate noun can be replaced by lexical variants. However, that is not the case with ser de 'be of' which has no stylistic nor aspectual variants. Nonetheless, these predicate nouns may have equivalent constructions with other elementary support verbs, mostly ter 'have', haver 'there be', and, more rarely, with fazer 'do, make'6 (see examples in Table 2).

\footnotetext{
${ }^{6}$ The construction with fazer is not strictly a paraphrase of the construction with ser de, as the former only characterizes the human gesture, but not the human quality expressed by the constructions with ser de.
} 
Table 1: Distribution of nominal predicates with support verb ser de by class attribute

\begin{tabular}{|c|c|c|}
\hline \multirow{2}{*}{$\begin{array}{l}\text { Class } \\
\text { SdH1 }\end{array}$} & \multicolumn{2}{|c|}{$\begin{array}{r}\text { Count Percentage Structure } \\
\text { Example }\end{array}$} \\
\hline & 388 & $\begin{array}{l}19 \%(\text { Nhum })_{0} \text { ser de } N \\
\text { O Zé é de uma alegria contagiante } \\
\text { Zé is of a contagious joy/happiness }\end{array}$ \\
\hline $\mathrm{SdH} 2$ & 54 & $\begin{array}{l}3 \%(\text { Nhum })_{0} \text { ser de } N \text { Prep } N_{1} \\
\text { O Zé é da confiança da Ana } \\
\text { Zé is from Ana's trust }\end{array}$ \\
\hline SdNH1 & 363 & $\begin{array}{l}17 \%(\text { Nnhum })_{0} \text { ser de } N \\
\text { Este molho é de uma acidez exagerada } \\
\text { This sauce is of an exaggerated acidity }\end{array}$ \\
\hline $\mathrm{SdNH} 2$ & 30 & $\begin{array}{l}1 \%(\text { Nnhum })_{0} \text { ser de } N \text { Prep } N_{1} \\
\text { Esta substância é de uma total indissolubilidade em água } \\
\text { This substance is of a total indissolubility in water }\end{array}$ \\
\hline SdNPC & 30 & $\begin{array}{l}1 \%(\mathrm{Npc} \text { de } \mathrm{Nhum})_{0} \text { ser de } N \\
\text { O rosto da Ana era de uma palidez doentia } \\
\text { Ana's face was of a sick pallor }\end{array}$ \\
\hline SdQ0 & 820 & $\begin{array}{l}39 \% Q_{u e F_{0}} \text { ser de } N \\
\text { Essa medida é de grande abrangência } \\
\text { This measure is of broad coverage }\end{array}$ \\
\hline SdQ1 & 308 & $\begin{array}{l}\text { 15\% QueF } F_{0} \text { ser de } N \text { Prep } N_{1} \\
\text { O Zé foi de uma agressividade desproporcionada para com a Ana } \\
\text { Zé was disproportionately aggressive towards Ana }\end{array}$ \\
\hline SdQ2 & 37 & $\begin{array}{l}2 \% N_{0} \text { ser de } N \text { Prep } Q u e F_{1} \\
\text { O Zé é de uma grande habilidade para tratar das roseiras } \\
\text { Ze is of great ability to treat rose bushes }\end{array}$ \\
\hline SdSIM & 55 & $\begin{array}{l}\text { 3\% } N_{0} \text { ser de } N \text { Prep } N_{1} \text { [symmetry] } \\
\text { O Zé e a Ana são de um companheirismo exemplar } \\
\text { Zé and Ana are of exemplary companionship }\end{array}$ \\
\hline otal & 2000 & \\
\hline
\end{tabular}

Table 2: Paraphrasing ser de variants

\begin{tabular}{|l|l|}
\hline Type & Paraphrases \\
\hline [Vsup=ter] & $\begin{array}{l}\text { O Pedro teve uma grande gentileza (para com a Maria) } \\
\text { Pedro had a great kindness (towards Maria) }\end{array}$ \\
\hline$[$ Vsup=fazer $]$ & $\begin{array}{l}\text { O Pedro fez uma grande gentileza (à Maria) } \\
\text { Pedro did a great kindness (to Maria) }\end{array}$ \\
\hline$[$ Vsup=haver $]$ & $\begin{array}{l}\text { Há no Pedro uma grande gentileza (para com a Maria) } \\
\text { There is in Pedro a great kindness (with Maria) }\end{array}$ \\
\hline
\end{tabular}

\subsection{Nominalizations}

An important source for the analysis of paraphrastic relations among sentences is nominalizations, that is, equivalence relations between sentences with a predicate noun and a support verb, on the one hand, and a verb or an adjective (and its auxiliary verb), on 
the other hand. For the most part, the predicate nouns with support verb ser de correspond to the nominalization of adjectival constructions, e.g. O Pedro foi de uma grande crueldade para com o João 'Pedro was of a great cruelty towards João' $=O$ Pedro foi muito cruel para com o João 'Pedro was very cruel to João'. More rarely, a verbal construction can be found: $O$ Pedro foi de uma grande compaixão para com o João 'Pedro was of (=had) a great compassion for João' = O Pedro compadeceu-se do João 'Pedro took pity on João'. It should be noted, however, that the lexical-morphological relation between a predicate noun and a verb, or between a noun and an adjective, is necessary but insufficient to establish a nominalization, with a transformational status, in the sense of Gross 1981; Harris 1981. Not only the meaning of the sentences being related must be the same, but the distributional constraints of the predicate noun on its argument domain must be similar. Establishing such paraphrastic status, thus, requires highly granular, and systematic linguistic description.

\subsection{Negation}

In the lexicon-grammar of ser de, two types of negation were formalized: (i) prefixation, i.e., possibility of adding/removing a negative prefix like des- or in- to the predicate noun; and (ii) analytic negation involving the expression falta de 'lack of 7 . Table 3 illustrates these two types of negation and the paraphrastic relation between them was represented in grammars displayed in Section 4.2. Whenever significant differences in meaning are found between the predicates starting with different negation prefixes, the prefixed and the base forms were treated as independent lexicon-grammar entries.

Table 3: Paraphrasing negation

\begin{tabular}{|l|l|}
\hline Type & Paraphrases \\
\hline$[$ in-N] & $\begin{array}{l}\text { O Pedro é de uma certa (in-)tolerância à lactose } \\
\text { Pedro is of a certain (in-)tolerance to lactose }\end{array}$ \\
\hline$[$ falta de N] (lack of N) & $\begin{array}{l}\text { O Pedro é de uma certa (falta de) tolerância à lactose } \\
\text { Pedro is of a certain (lack of) tolerance to lactose }\end{array}$ \\
\hline
\end{tabular}

\subsection{Appropriate Nouns and NP Restructuring}

The subject of the sentences with ser de 'be of' is many times a complex noun phrase (NP) whose head is also a predicate noun. This head may occur with its arguments, particularly its semantic/notional 'subject' argument, in the form of a prepositional phrase (PP) introduced by the preposition de 'of': [A disposição destes objetos] é de uma certa assimetria '[The placement of these objects] is of a certain asymmetry'. An appropriate relation, in the sense of Gross 1981 [pp. 113-115], Harris 1976, usually exists between the predicate noun in the subject position and the sentence's main predicate, and a NP restructuring operation (Guillet and Leclère 1981) is then found, which splits the noun

\footnotetext{
${ }^{7}$ Most of the predicates having this property express human qualities/attributes.
} 
phrase into two distinct constituents: (i) the head of the PP becomes the sentence subject, while (ii) the predicate noun (formerly the head of the subject NP) is moved to a new PP, usually at the end of the sentence. For example, in [Estes objetos] são de uma certa assimetria [na sua disposição] '[These objects] are of a certain asymmetry [in their placement]', the reference of the possessive determiner in the PP (sua 'their', in the example) is constrained, and it has to refer to the subject of the predicate noun; obviously, this possessive can not be derived from a free PP, non-co-referent to the subject. The semantic roles of the elements are then kept exactly the same in spite of the formal changes the sentence undergoes.

\subsection{Manner Sub-clauses Restructuring}

An interesting distributional constraint regards the subject NPs with manner operator nouns (Gross 1975) forma, maneira and modo 'manner/way' (in Brazilian Portuguese, there is also the operator noun jeito 'idem'). These operators can be construed with an infinitive sub-clause complement introduced by preposition de 'of': A formala maneiralo modo de o Pedro fazer isso é de uma arrogância impressionante 'The way of Pedro doing this is of an impressive arrogance'; or a pseudo-relative, finite clause, introduced by the so-called interrogative adverb como 'how': A formala maneiralo modo como o Pedro faz isso é de uma arrogância impressionante 'The way how Pedro does this is of an impressive arrogance'. When the predicate noun accepts these operator nouns, these sentences qualify the way a process takes place or the manner in which an action is performed, rather than expressing the attributes of a person or an object. A similar NP restructuring as seen above (3.5) operates on these manner constructions, splitting the complex NP, extracting the subject of the subordinate clause to the subject of the predicate noun and leaving the operator noun as a PP manner complement: O Pedro é de uma arrogância impressionante em_a formala maneiralo modo de fazer isso 'Pedro is of an impressive arrogance in the way of doing that' $O$ Pedro é de uma arrogância impressionante em_a formala maneiralo modo como faz isso 'Pedro is of an impressive arrogance in the way [he] does that'.

Table 4: Paraphrasing manner sub-clauses

\begin{tabular}{|c|c|}
\hline Type & Paraphrases \\
\hline$[$ RestNopQueF] & $\begin{array}{l}\text { O modo de o Pedro agir é de uma certa teimosia } \\
\text { Pedro's way of acting is of a certain stubbornness } \\
\text { O Pedro é de uma certa teimosia no seu modo de agir } \\
\text { Pedro is of a certain stubbornness in his way of acting }\end{array}$ \\
\hline$[$ RestNopQueF] & $\begin{array}{l}\text { O modo como o Pedro age é de uma certa teimosia } \\
\text { The way Pedro acts is of a certain stubbornness } \\
\text { O Pedro é de uma certa teimosia no modo como age } \\
\text { Pedro is of a certain stubbornness in the way he acts }\end{array}$ \\
\hline
\end{tabular}




\subsection{Reduction of Finite Sub-clause to Infinitive and Restructuring}

Other sub-clause transformations have also been represented in the lexicon-grammar, namely the possibility of an infinitive construction with operator-noun facto (fact), the reduction of a finite sub-clause to an infinitive and its restructuring in a way similar to the NP restructuring transformations seen above. Table 5 illustrates these phenomena.

Table 5: Paraphrasing manner sub-clauses

\begin{tabular}{|c|c|}
\hline Type & Paraphrases \\
\hline [Nop facto] & $\begin{array}{l}E \text { de uma completa evidência que a Susana está a mentir } \\
\text { It is of a complete evidence that Susana is lying } \\
\text { É de uma completa evidência o facto de a Susana estar a mentir } \\
\text { It is of a complete evidence the fact that Susana is lying }\end{array}$ \\
\hline$[$ Vinf $]$ & $\begin{array}{l}\hat{E} \text { de uma certa teimosia que o Pedro aja assim } \\
\text { It is of a certain stubbornness that Pedro acts in that way } \\
\text { É de uma certa teimosia o Pedro agir assim } \\
\text { Is of a certain stubbornness Pedro acting that way }\end{array}$ \\
\hline [Rest Vinf $]$ & $\begin{array}{l}\text { O Pedro é de uma certa teimosia em agir assim } \\
\text { Pedro is of a certain stubbornness in acting in this way }\end{array}$ \\
\hline
\end{tabular}

\section{Integration of Lexicon-Grammar Tables in Port4NooJ}

As shown in Mota, Chacoto, and Barreiro 2017 and Mota, Carvalho, and Barreiro 2016, the integration of lexicon-grammars in Port4Nooj is a two-step process. First, one converts the lexicon-grammar tables into NooJ dictionary format, and then one builds grammars that use the linguistic knowledge encoded in the lexicon-grammar tables to identify relevant sentences or phrases and generate their corresponding paraphrases.

\subsection{From Lexicon-Grammar Tables to NooJ Dictionaries}

The procedure described in Mota, Chacoto, and Barreiro 2017 to convert the lexicongrammar entries that occur with support fazer into a standalone dictionary was adopted, with minor adjustments, to convert the lexicon-grammar entries that occur with support verb ser de. The procedure is illustrated in Figure $2 .^{8}$

The minor adjustments were related to particularities of the lexicon-grammars properties or format that do not interfere with the overall procedure, but only with the way lexicon-grammar properties are converted into dictionary attributes. For example, the

\footnotetext{
${ }^{8}$ As in Mota, Chacoto, and Barreiro 2017, the procedure allows to check whether words are compliant with the Portuguese Orthographic Agreement, but since all the words are preAgreement we are not using that feature and, hence, it is not described in the figure.
} 


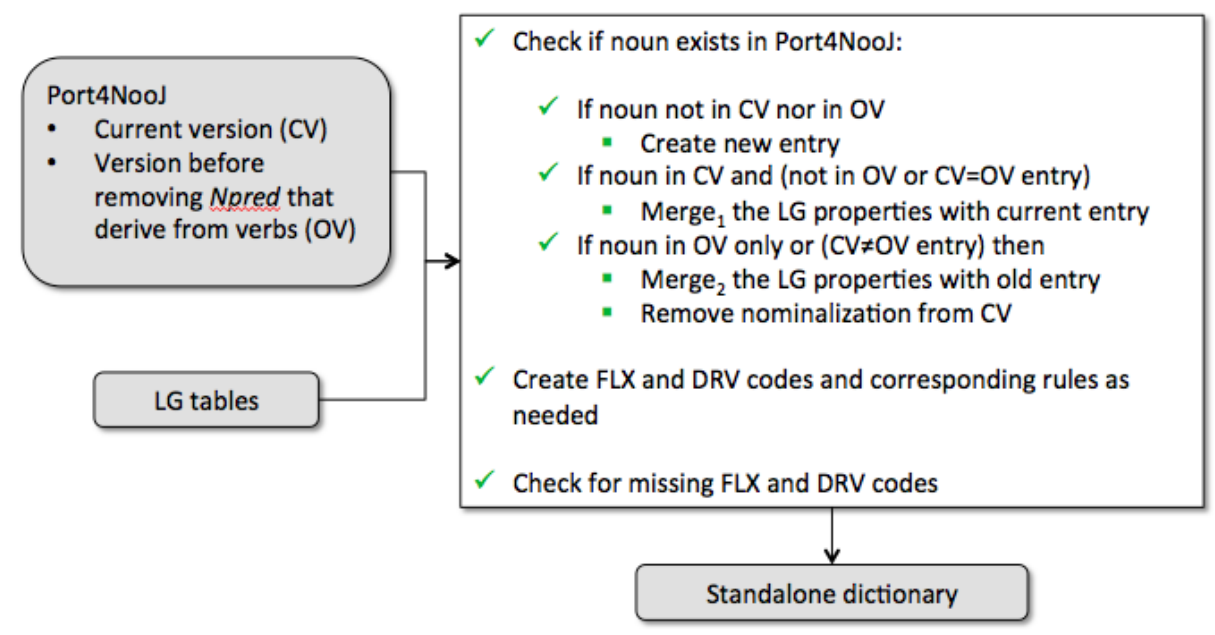

Fig. 2: Integration of LG entries in Port4NooJ

property PfxNeg can be filled in the lexicon-grammar entries with "-" when the predicate does not accept a negative prefix or with the value of the negative prefix, e.g., in-, des-.

The new standalone dictionary is comprised of 2,134 predicate noun entries that occur with Vsup ser de, corresponding to 1,376 different lemmas. Additional 797 entries await revision to be added to this version of the dictionary. They need revision of the inflectional codes, of derived adjectives or have problems with their format. The integration of this lexicon-grammar led to the creation of 450 new derivational paradigms, but there might be an overlap with paradigms created when integrating the lexicongrammar of constructions with the support verb fazer.

$50 \%$ of the predicate nouns in the lexicon-grammar already existed in the main dictionary of Port4Nooj. This corresponds to a 6\% increase in nominal entries and $20 \%$ increase in predicate nouns. In 55\% of the cases where the predicate nouns have an equivalent adjectival construction, the adjective was homograph of a human intransitive adjective, already formalized in the lexicon-grammar of human intransitive adjectives Carvalho (2007). This overlap implies harmonization of entries in order to eliminate duplicates.

It is also worth noting that $4 \%$ of the predicate noun lemmas (52) that occur with support verb ser de are homographs of predicate noun lemmas that occur with support verb fazer, which had been previously integrated in Port4NooJ. Some predicates correspond to the same construction, like $O$ Zé é de uma patetice impressionante 'Zé is of an impressive goofiness' seems a paraphrase of $O$ Zé fez uma patetice 'Zé did a goofiness', which can be confirmed also by the fact that the entry for patetice accepts the Vsup fazer as a valid substitution for the Vsup ser de. Other predicate nouns, like reserva 'reservation' in $O$ Zé foi de uma grande reserva para com a Ana em relação à sua decisão 'Ze was a of big reservation with Ana about her decision', and in $O$ Tó fez a reserva do bilhete 'Tó made the ticket reservation', are not expressions of the same 
predicate. Further studies need to be made to see whether it is worth merging those entries together.

\subsection{From Lexicon-Grammar Tables to NooJ Grammars}

As we have already shown in Mota, Carvalho, and Barreiro 2016 and Mota, Chacoto, and Barreiro 2017, the process of integrating the lexicon-grammar with Port4NooJ dictionary entries is mostly automatic, but the process of creating the grammars that use the knowledge formalized in the lexicon-grammars is hand-crafted, hence, timeconsuming. Some grammars can still be reused when they represent similar phenomena common to different lexicon-grammars although they usually need to be updated with the information of the newly integrated lexicon-grammar tables. The grammar that allows the substitution of the support verb by another support verb is one of such cases, as well as the grammar built to represent the equivalence between symmetric predicates, where the arguments have been swapped or coordinated. See Figure 3 as an example of the latter. As illustrated in the figure, the equivalent adjectival constructions is also recognized and generated. In that case, the grammar guarantees the agreement in gender and in number with the subject (where the arguments have been coordinated or not) and the adjective.

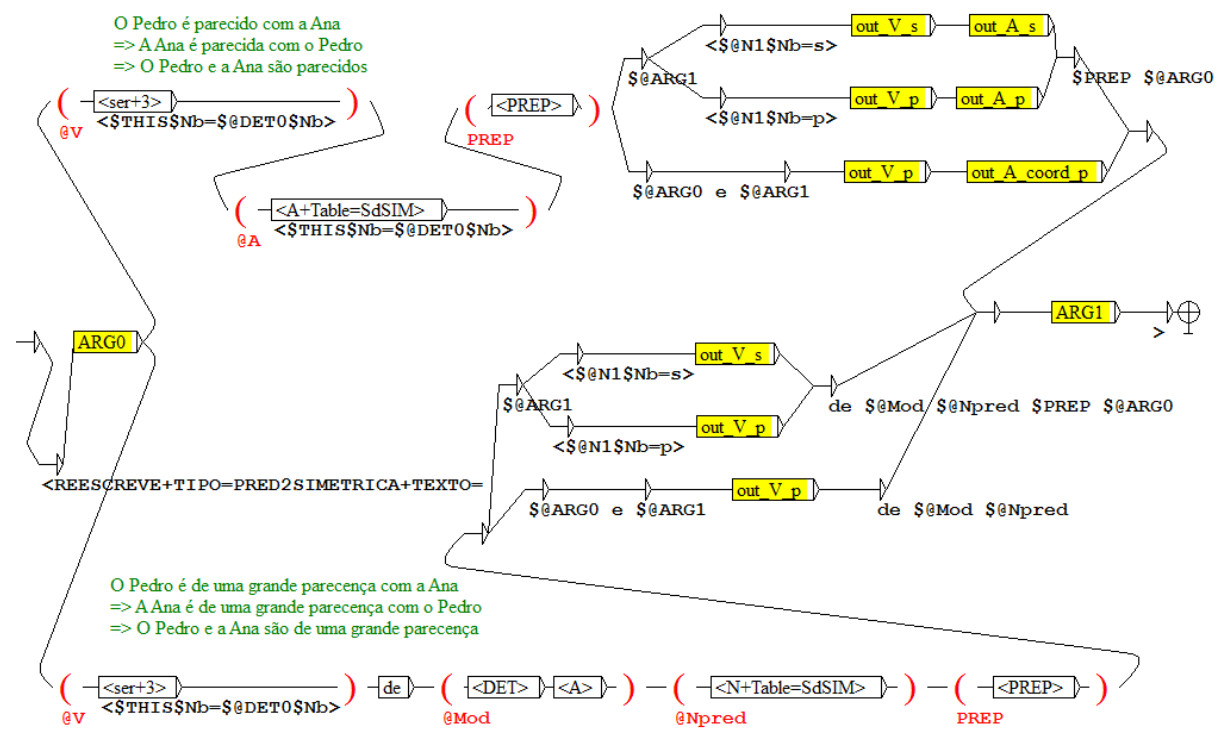

Fig. 3: Grammar for paraphrasing of symmetric constructions

Figure 4 shows the annotations that were added to the NooJ Text Annotation Structure after doing the linguistic analysis including the grammar that generates the paraphrasing of symmetric predicates illustrated in Figure 3. Although the adjectival form 
parecida 'resembling' is feminine-singular, when swapping the argument of the adjective, it becomes masculine-singular to agree in gender-number with the noun irmão 'brother; also, the adjective becomes masculine-plural to agree with the coordinated arguments, e.g. a mulher $e$ o irmão 'the woman and the(=her) brother', since in Portuguese, whenever there is a masculine noun in coordinated noun phrases, the adjective is obligatorily inflected in the masculine form.

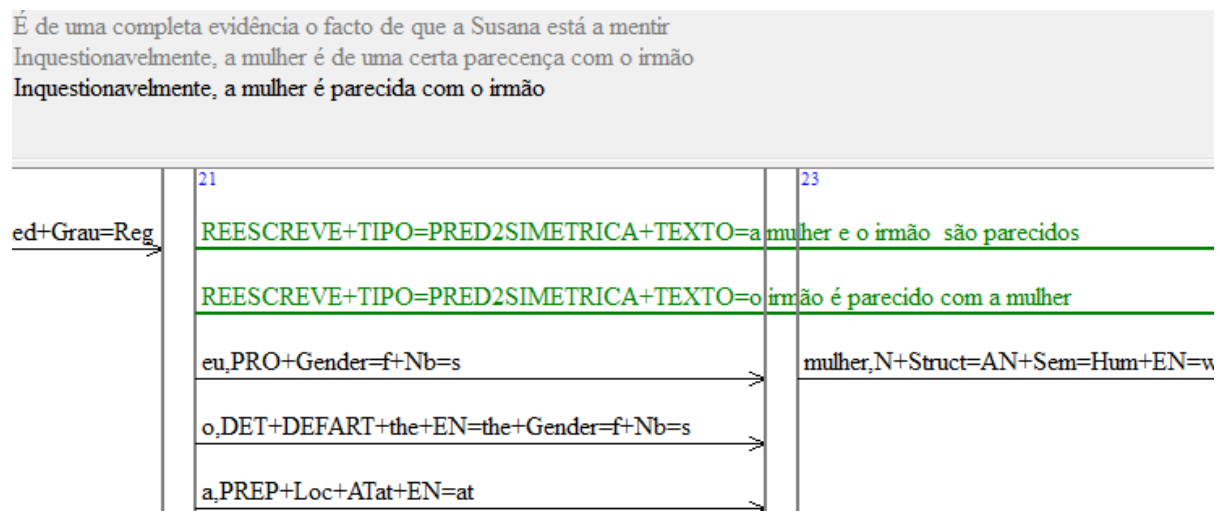

Fig. 4: Annotation and paraphrase generation of symmetric constructions

While developing new grammars, we encountered two new features that we had not encountered before: (1) we had to make use of more than one lexicon-grammar property to create the criteria to generate the paraphrase - in particular, to generate paraphrases of negative constructions, the predicate must have both attributes PfxNeg and Negfaltade, otherwise it is not enough to establish the paraphrastic relation between the two constructions; (ii) we established unidirectional paraphrases, i.e., we identify, for example, the construction $\mathrm{A}$ and generate the construction $\mathrm{B}$; but we do not identify $\mathrm{B}$ and generate $\mathrm{A}$ - this happened when we need a larger context or a more complex analysis to be able to rephrase $\mathrm{A}$ given $\mathrm{B}$, such as in the case of rephrasing a possessive with the appropriate noun phrase.

\section{Conclusions and Future Work}

This paper reported the progress of integration of existing lexicon-grammar tables in Port4NooJ, in continuity with previous integration efforts. This time, we have added 2,134 predicate nouns with Vsup ser de to our dictionary of predicate nouns, corresponding to 1,376 different noun lemmas. Half of the nouns already existed in the previous version of Port 4 NooJ $(50 \%)$, which corresponds to a $6 \%$ increase in the number of nominal entries and a $20 \%$ increase in the number of predicate nouns for the current version of the Port4NooJ dictionary. Additional 797 entries await revision of the inflectional codes of the corresponding derived adjectives, or have format problems that require a fix prior to being added to this version. In addition, 450 new derivational 
paradigms were created, though some of them might overlap with paradigms already created, when integrating the predicate nouns used with the Vsupfazer. We have created some experimental grammars to generate production scale batches of paraphrases for different linguistic phenomena and exemplified paraphrasing with symmetric constructions in the NooJ syntactic parser. Our next steps will focus in four different axes: (i) consolidate and harmonize dictionaries, (ii) continue building lexicon-grammar-based paraphrasing grammars, (iii) review dictionaries and grammars, and (iv) integrate new lexicon-grammars, thus re-initiating the cycle. The new paraphrases can be immediately integrated in the eSPERTo system, because they are $100 \%$ precise and can serve the purposes of exploring language learning applications by using chatbots, a usage scenario in which our efforts are now engaged.

\section{Acknowledgements}

This research was supported by Fundação para a Ciência e Tecnologia (FCT), under exploratory project eSPERTo (Ref. EXPL/MHC-LIN/2260/2013). Anabela Barreiro was also funded by FCT through post-doctoral grant SFRH/BPD/91446 /2012. Jorge Baptista's Ph.D. research has been funded by a scholarship under program Praxis XXI (2001-2004) and subsequent, more recent research, has been funded by the R\&D Units Program (ref. UID/CEC/50021/2013). The authors would like to thank Max Silberztein for his prompt support and guidance with all matters related to NooJ.

\section{References}

Baptista, Jorge (2000). "Sintaxe dos Predicados Nominais construídos com o verbosuporte SER DE”. PhD thesis. Universidade do Algarve, Faro, Portugal.

- (2005a). "Construções simétricas: argumentos e complementos". In: Estudos de homenagem a Mário Vilela. Ed. by Olga Figueiredo, Graça Rio-Torto, and F. Silva. Faculdade de Letras da Universidade do Porto, pp. 353-367.

- (2005b). Sintaxe dos predicados nominais com 'ser de'. Lisboa: Fundação Calouste Gulbenkian, Fundação para a Ciência e a Tecnologia.

Barreiro, Anabela et al. (2011). "OpenLogos Rule-Based Machine Translation: Philosophy, Model, Resources and Customization”. In: Machine Translation 25.2, pp. 107126.

Carvalho, Paula (2007). “Análise e Representação de Construções Adjectivais para Processamento Automático de Texto. Adjectivos Intransitivos Humanos”. PhD thesis. Universidade de Lisboa, Lisboa, Portugal.

Chacoto, Lucília (2005). “O Verbo Fazer em Construções Nominais Predicativas”. PhD thesis. Universidade do Algarve, Faro, Portugal.

D’Agostino, Emilio and Annibale Elia (1998). "Il significato delle frasi: un continuum dalle frasi semplici alle forme polirematiche”. In: AA. VV, Ai limiti del linguaggio. Bari: Laterza, pp. 287-310.

Gross, M. (1975). Méthodes en syntaxe: régime des constructions complétives. Actualités scientifiques et industrielles. Hermann. 
Gross, Maurice (1981). "Les bases empiriques de la notion de prédicat sémantique". In: Langages 15.63 , pp. 7-52.

- (1996). "Lexicon-Grammar". In: Concise Encyclopedia of Syntactic Theories. Ed. by Keith ; Brown and Jim Miller. Cambridge: Pergamon, pp. 244-259.

Guillet, Alain and Christian Leclère (1981). "Restructuration deu group nominal". In: Langages 63, pp. 99-125.

Harris, Zellig S. (1981). “The Elementary Transformations”. In: Papers on Syntax. Ed. by Henry Hiż. Dordrecht: Springer Netherlands, pp. 211-235. ISBN: 978-94-0098467-7.

Harris, Zellig Sabettai (1976). Notes du Cours de Syntaxe. Ed. by Maurice Gross. Paris: Seuil.

Laporte, Eric and Stavroula Voyatzi (2008). "An electronic dictionary of French multiword adverbs". In: Language Resources and Evaluation Conference. Workshop Towards a Shared Task for Multiword Expressions, pp. 31-34.

Mamede, Nuno et al. (2012). "STRING - A Hybrid Statistical and Rule-Based Natural Language Processing Chain for Portuguese". In: Computational Processing of the Portuguese Language (PROPOR 2012). Vol. Demo Session. PROPOR. Coimbra, Portugal: PROPOR, s/p.

Mota, Cristina, Paula Carvalho, and Anabela Barreiro (2016). "Port4NooJ v3.0: Integrated Linguistic Resources for Portuguese NLP”. In: Proceedings of the Tenth International Conference on Language Resources and Evaluation LREC 2016, Portorož, Slovenia, May 23-28, 2016.

Mota, Cristina, Lucilia Chacoto, and Anabela Barreiro (2017). "Integrating the LexiconGrammar of Predicate Nouns with Support Verb fazer into Port4NooJ". In: Formalizing Natural Languages with NooJ and Its Natural Language Processing Applications, 11th International Conference, NooJ 2017, Kenitra and Rabat, Morocco, May 18-20, 2017, Revised Selected Papers. Springer.

Rassi, Amanda et al. (2014). "The fuzzy boundaries of operator verb and support verb constructions with dar "give" and ter "have" in Brazilian Portuguese". In: Proceedings of the Workshop on Lexical and Grammatical Resources for Language Processing (LG-LP 2014), COLING 2014. Workshop on Lexical and Grammatical Resources for Language Processing (LG-LP 2014), COLING 2014, Dublin, August 24, 2014. Dublin, Ireland: COLING 2014.

Rassi, Amanda Pontes et al. (2015). "Integrating support verb constructions into a parser". In: Symposium in Information and Human Language Technology (STIL 2015). Ed. by SBC. SBC. Natal (Brasil).

Salkoff, Morris (1990). "Automatic Translation of Support Verb Constructions". In: Proceedings of the 13th Conference on Computational Linguistics - Volume 3. COLING '90. Helsinki, Finland: ACL, pp. 243-246.

Scott, Bernard (2018). Translation, Brains and the Computer: A Neurolinguistic Solution to Ambiguity and Complexity in Machine Translation.

Silberztein, Max (1993). "Les groupes nominaux productifs et les noms composés lexicalisés”. In: Lingvistica Investigationes 17.2, pp. 405-425.

- (2016). Formalizing Natural Languages: the NooJ Approach. Wiley Eds., p. 346. 